\author{
Alexander N. \\ Alekseev \\ Svetlana V. Lobova \\ Aleksei V. Bogoviz ${ }^{1}$
}

Article info: Received 30.08.2020. Accepted 16.12.2020.

UDC -005.591 .6$ DOI - 10.24874/IJQR15.03-04

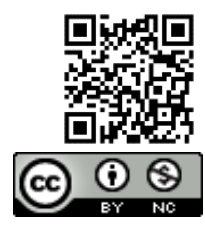

\section{DIGITALIZATION AND QUALITY OF LABOR: CONTRADICTIONS IN DEVELOPING COUNTRIES AND THE PROSPECTS OF HARMONIZATION}

Abstract: This paper aims at determining the influence of digitalization on quality of labor in developing countries. Originality and novelty of this research consist, firstly, in specifying the characteristics and systemic treatment of quality of labor in view of the priorities of all interested parties - entrepreneurship, employees, and government. Secondly, the influence of digitalization on quality of labor is studied in detail at the empirical level of economics with the use of statistical data, which allows determining precise causal connections and forming a reliable evidential base of the considered concept. Thirdly, an assumption of contradiction of the influence of digitalization on quality of labor is a new one. This influence is not treated positively a priori-instead of this, we offer a hypothesis on the combination of the positive and negative influence, which is verified in the course of the research. Fourthly, experience of developing countries is studied, which allows determining the specifics of the influence of digitalization on quality of labor in these countries as compared to developed countries. This will help differentiating the practices of digitalization from the positions of the consequences for labor quality and developing separate approaches for labor quality management in the digital economy of developing countries. Fifthly, digitalization is specified, and the influence of various directions of digitalization on quality of labor is studied. This allows obtaining detailed conclusions and compiling highly-effective practical recommendations. As a result, it has been determined that the maximum systemic growth of characteristics of labor quality based on digitalization in developing countries in the period until 2024 constitutes $78.63 \%$. Harmonization of digitalization in developing countries for the purpose of increasing labor quality envisages increase of the level of development of digital technologies by $68.83 \%$ and digital perspectives by $46.22 \%$. Management implications are offered for this.

Keywords: Quality of labor; Digitalization; Contradictions; Developing countries; Prospects of harmonization.

\section{Introduction}

In the modern society and economy, labor should be evaluated from the positions of quality, for its increase is of the highest priority for all interested parties. Entrepreneurship uses human resources as a manifestation of labor in quality of the key production factor for the purpose of

1 Corresponding author: Aleksei V. Bogoviz

Email: aleksei.bogoviz@gmail.com 
increasing the effectiveness of the use of other factors by means of accumulation and exchange of knowledge and improvement of technologies. Workers use their labor for realizing their intellectual potential. The higher the quality of labor, the wider the opportunities of increase of income and career building. Human resources also determine the competitiveness of an economic system and opportunities of its economic growth and development - thus, quality of labor is of interest for government. Despite the high importance and vivid practical significance, the concept of labor quality has a lot of gaps.

One of the gaps is the lack of the systemic characteristics of labor quality. In the existing studies, focus is made on the interests of entrepreneurship. If labor treated as a production factor, its quality is equaled to quality of the manufactured products - its technical characteristics and absence of defects. This "narrow" treatment of labor quality does not take into account the interests of employees and government and distorts the interests of entrepreneurship. In particular, a lot of modern companies manifest corporate social responsibility and use labor in the interests of business, as well as create advantages for employees for training and realization of creative potential, obtaining marketing advantages. Without a clear idea of labor quality, its scientific research and management is difficult.

Another gap is obscureness of the influence of digitalization on quality of labor, though it is one of the factors of its increase. It is generally known that digitalization stimulates labor authomatization and raises efficiency; however, the consequences of digitalization, in particular for motivation and labor stimulation, are not studied enough. Another gap is connected to generalization of digitalization, which is actually rather different and has several directions. Experience of developed countries shows that the fuller the digitalization, the more it stimulates the increase of labor quality. Thus, digitalization of knowledge ensures training of digital personnel, but quality of their labor will be higher as compared to other employees only under the conditions of application of digital technologies.

Another gap is insufficient elaboration of the causal connections of labor digitalization in the aspect of quality. A popular belief in the positive influence of digitalization on quality of labor has not been confirmed by science. In practice, there might be a situation when competitiveness of products that are manufactured with the use of manual labor (hand made) is higher as compared to conveyor products - due to uniqueness. This depends on consumers preferences. Automatization based on digital technologies, accompanied by staff cuts, could undermine motivation for labor with the remaining employees and reduce quality of their labor.

Other gaps also include generalization of the experience of digitalization and its influence on quality of labor, which could be rather specific in practice. Experience of developed countries shows the increase of labor quality in case of digitalization, due to creation of a larger number of highly-efficient and wellpaid jobs and expansion of the opportunities for realization of employees' human potential. Depending on them, an opposite situation could take place in developing countries, which experience is accumulated and has not been studied in detail yet. Automatization of production could mean increase of unemployment and creation of low-paid jobs on maintenance of digital technologies and reduction of opportunities for human potential realization. Quality of human labor and manufactured products might decrease due to growth of defects in automatized production.

For filling the above mentioned gaps and forming a scientific concept of labor quality, this work aims at determining the influence of digitalization on quality of labor in developing countries. Originality and novelty of this research consist, firstly, in 
specifying the characteristics systemic treatment of labor quality in view of the priorities of all interested parties entrepreneurship, employees, and government. Secondly, the influence of digitalization on quality of labor is studied at the empirical level of economics with the use of statistical data, which allows determining precise causal connections and forming a reliable evidential based of the considered concept.

Thirdly, a new assumption is the idea of contradiction of the influence of digitalization on labor quality. This influence is not treated positively a priori - instead, we offer a hypothesis on combination of the positive and negative influence, which is verified in the course of the research. Fourthly, the experience of developing countries is studied, which allows determining the specifics of the influence of digitalization on quality of labor in these countries as compared to developed countries. This will help to differentiate the practices of digitalization from the positions of consequences for labor quality and to develop separate approaches for labor quality management in the digital economy of developing countries. Fifthly, digitalization is specified, and the influence of various directions of digitalization on labor quality is studied. This allows for detailed conclusions and highly-effective practical recommendations.

The above determines the logic and structure of this research. This introduction is followed by literature review, with theoretical basis and gap analysis. Materials and methods contain the information and empirical basis of the research and its algorithm. The results include the following: 1) Contradictions of the influence of digitalization on quality of labor in developing countries; 2) prospects of harmonization of the directions of digitalization in developing countries for the purpose of increasing labor quality; 3) management implications for digitalization management in developing countries for the purpose of increasing labor quality. Conclusions are given at the end of the paper.

\section{Literature Review}

Labor quality is studied in the following works. Pandey (2018) offers managing emotional labor for service personnel and develops a scientific and methodological approach based on HRM (human resource management). Bachmann (2019) notes a vivid change of households' consumption in the context of changes in the labor market in Japan in 1984-2014. Yadav (2020) studies the cultural rights of labor in maritime employment in India.

Wang et al. (2017) performs an analysis of labor division in the system of e-commerce transactions based on the number of main services. Oguzertem (2019) determines the main obstacles on the path of integration of displaced population to labor markets and offers steps for overcoming them. Sarkar and Liu (2019) track the influence of the changing relations between unions and political part on the growth of autonomous unions in Taiwan.

Fan et al. (2018) point out that unions alleviate labor conflicts at production companies of China (based on the data of a Chinese survey of employers and employees). Calavrezo (2007) determine the influence of the number of urgent jobs on integration of high school graduates in the labor market (based on the data from France).

Susilowati et al. (2019) determine the specifics of labor efficiency in micro spheres and small spheres (based on a study of leather dressers). Savoia et al. (2016) deem it necessary to unify technical knowledge and human resources with the goal to contribute to transformation of the Adriatic Sea into a stable center of sustainable technological development. Stanovcic et al. (2016) substantiate the role of HR practice in income from innovations, as well as the role 
of support of top management and regularity of employees' meetings.

Transformation of the essence of labor and the role of human resources in society, economy, and entrepreneurship in the conditions of transition to the digital economy and Industry 4.0 is studied in the following works. Bucher et al. (2019) form a philosophical basis of digital labor and study it as matter. Bejaković and Mrnjavac (2020) prove the importance of digital literacy in the labor market.

Aboobaker and K.A. (2019) outline the influence of orientation at digital training and readiness for changes at the innovative labor behavior (based on the ideas on the higher education sector). Baro et al. (2019) perform evaluation of the digital literacy skills and competences that are based on knowledge with librarians of university libraries in Africa. Okeji et al. (2019) study digital literacy and competencies that are based on knowledge with librarians in university libraries of Nigeria.

The specifics of use of human resources and labor as a production factor in developing countries are outlined in the following works. Garcia-Carbonell et al. (2018) study human capital in top management teams through the prism of top HR managers. Maurer (2017) sets the task of creating programs of support for HR management. Lekchiri (2017) notes the regional and national perspectives of global development of human resources.

Ishmael-Robertson (2018) determines the key achievements in development of human resources, which will be necessary for tourism in Guyana by 2025 . DiClaudio (2019) determines the connection between HR analytics and development of human resources and substantiates that data, analytics, and new technologies could turn human resources (HR) into a source of revenue. Jha and Bhattacharyya (2017) prove the change of contours of strategic management of human resources in India.

Das (2019) shows that diversity management is a strategic direction for human resources and provides criticism and a road map. Amladi (2017) offers a guide for HR management in digital transformation and substantiates ten scenarios of the use of digital economy for transformation of human resources in production. Plaskoff (2017) analyzes experience of employees and develops a new approach to human resources management in the digital economy.

Experience of digitalization of developing countries' economies is presented in the works Alpidovskaya and Popkova (2019), Inshakova and Bogoviz (2020), Popkova and Sergi (2020), Popkova (2017), Popkova (2019), Popkova (2020), Popkova et al. (2020), Popkova et al. (2017), Popkova and Sergi (2018), Popkova and Sergi (2019), Ragulina (2019), and Shulus et al. (2020).

Sergi et al. (2019a) present a scientific idea of Industry 4.0 from the positions of AI, the Internet of Things, and future professions. Sergi et al. (2019b) determine the connection between entrepreneurship and economic growth (analyzing and comparing the experience of developed and developing countries). Sergi et al. (2019c) determine the costs and profit of technological growth in Russia. Rana and Sharma (2019) note new practices of human resources management in Industry 4.0.

Irum and Yadav (2019) study the information systems of human resources and substantiate their strategic contribution to human resources management. Bogoviz et al. (2020a) oppose social development to economic growth, noting their current contradictions and perspectives of convergence. Bogoviz et al. (2020b) study the current state and perspectives of development of hydraulic power industry in Russia based on labor quality management. Bogoviz et al. (2019a) develop applied solutions for managing the modernization of educational services' regional markets in the conditions of formation of Industry 4.0. Bogoviz et al. (2019b) substantiate the experience of diversifying educational 
services in the conditions of Industry 4.0 and offer conducting it based on AI.

Thus, the literature review has shown a high level of elaboration of certain components of the set problem. However, there are a lot of fundamental and empirical gaps, which include elaboration of only certain characteristics of labor quality, surface study of the influence of digitalization on quality of labor, poor research of the experience of developing countries, and general domination of theoretical studied, as well as deficit of applied studies and insufficient factual basis of the concept of influence of digitalization on quality of labor in developing countries. In order to fill these gaps, we perform a systemic and detailed study of the influence of digitalization on quality of labor in developing countries.

\section{Materials and methodology}

In order to use the official statistics and obtain the most precise and correct results, the source of empirical data on digitalization is World Digital Competitiveness Report 2019, published by IMD (2020). In order to study the influence of digitalization (take into account all its manifestations) and obtain informative data, we use the generalized indicators (factors of digitalization) - digital knowledge (knowledge), digital technologies (technology), and digital perspectives (future readiness), - for they combine all detailed indicators, and their values are measured not in positions but in points. The characteristics of labor quality are as follows.

- Labor efficiency, the data on which are available for certain countries for 2019 in the materials OECD (2020) and for other countries for 2017-2018 in the materials Our World in Data (2020) - characteristics of effectiveness of using labor as a production factor, which reflects the volume of production over a certain period with fixed quality;

- Human development index according to Human Development Report 2019, prepared by UNDP (2020) - characteristics of qualification and competence of human resources as a limit of increase of labor quality;

- Stimulation of labor as the indicator "pay and productivity", according to The Global Competitiveness Report 2019, published by World Economic Forum (2020) characteristics of realization of potential of increase of labor quality based on management;

- Share of hi-tech products in industrial export as the indicator for 2018, calculated by World Bank (2020) - characteristics of global competitiveness of products as a manifestation of the result of labor from the positions of quality;

- Innovation index, presented in Global innovation Report 2019 and calculated by Cornell INSEAD WIPO (2020) characteristics of innovative activity of employees and realization of their creative potential for the purpose of increasing labor quality.

It should be noted that statistics of the technical characteristics of products and defects are not recorded and not available at the international level due to lack of the unified methodology and due to large intersector differences; we do not use here intracorporate data, in order to obtain the fullest and the most precise and correct data at the level of the global economy. Here we use the data as of 2020.

The research objects have been selected in view of countries' presence in the IMD ranking for 2019, which includes 63 countries (criterion of availability of data on digitalization) and in view of the economies' belonging to the category of developing countries according to the classification of the International Monetary Fund (2020), provided in World Economic Outlook Database (category "Emerging market and developing economies"). The data on the selected countries are systematized and presented in Table 1. 
Table 1. Statistics of digitalization and labor quality in developing countries in 2020.

\begin{tabular}{|c|c|c|c|c|c|c|c|c|}
\hline \multirow[b]{2}{*}{ Country } & \multicolumn{3}{|c|}{ Factors of digitalization } & \multicolumn{5}{|c|}{ Characteristics of labor quality } \\
\hline & 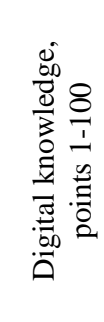 & 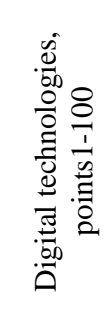 & $\begin{array}{l}0 \\
0 \\
0 \\
0\end{array}$ & 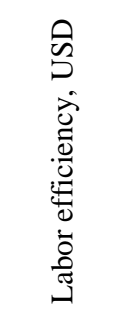 & 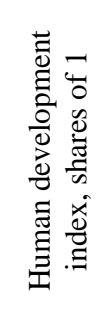 & 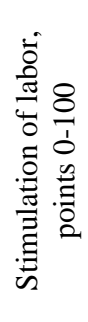 & 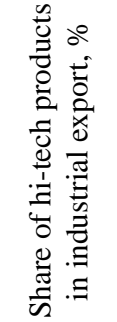 & 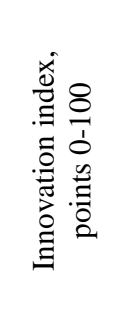 \\
\hline \multirow[t]{2}{*}{ - } & $\begin{array}{l}0 \\
\frac{0}{0} \\
\frac{0}{3} \\
0 \\
0 \\
0\end{array}$ & 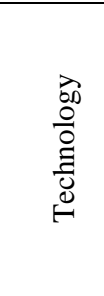 & 总 & 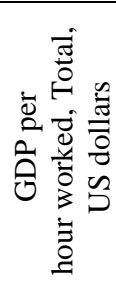 & 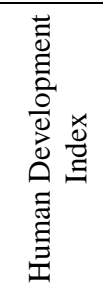 & 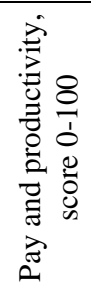 & 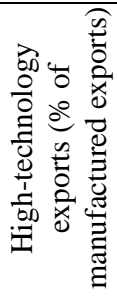 & 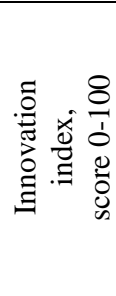 \\
\hline & $\mathrm{x}_{1}$ & $\mathrm{x}_{2}$ & $\mathrm{x}_{3}$ & $\mathrm{y}_{1}$ & $\mathrm{y}_{2}$ & $\mathrm{y}_{3}$ & $\mathrm{y}_{4}$ & $\mathrm{y}_{5}$ \\
\hline Chile & 53.772 & 62.034 & 63.156 & 25.66 & 0.847 & 56.0 & 7.0 & 36.64 \\
\hline Mexico & 53.505 & 53.589 & 52.930 & 20.32 & 0.767 & 46.4 & 21.0 & 36.06 \\
\hline Russia & 75.017 & 58.451 & 56.539 & 26.49 & 0.824 & 58.9 & 11.0 & 37.62 \\
\hline South Africa & 52.148 & 53.647 & 55.588 & 19.94 & 0.705 & 46.0 & 5.0 & 34.04 \\
\hline Turkey & 45.497 & 55.105 & 57.567 & 45.00 & 0.806 & 43.7 & 2.0 & 36.95 \\
\hline Romania & 56.658 & 57.765 & 52.633 & 33.76 & 0.816 & 44.6 & 11.0 & 36.76 \\
\hline Poland & 68.614 & 66.201 & 65.095 & 40.96 & 0.872 & 53.0 & 10.0 & 41.31 \\
\hline Hungary & 58.181 & 67.857 & 49.168 & 37.70 & 0.845 & 41.0 & 18.0 & 44.51 \\
\hline Bulgaria & 57.368 & 59.111 & 53.300 & 25.93 & 0.816 & 49.2 & 10.0 & 40.35 \\
\hline China & 78.067 & 72.856 & 80.743 & 10.68 & 0.758 & 60.5 & 31.0 & 54.82 \\
\hline Brazil & 45.742 & 49.166 & 55.919 & 16.34 & 0.761 & 40.4 & 13.0 & 33.82 \\
\hline India & 63.721 & 54.978 & 54.946 & 7.55 & 0.647 & 51.3 & 9.0 & 36.58 \\
\hline
\end{tabular}

Source: compiled by the authors based on Cornell INSEAD WIPO (2020), IMD (2020), OECD (2020), Our World in Data (2020), UNDP (2020), World Bank (2020), World Economic Forum (2020).

The algorithm of the research is presented in Figure 1. As shown in Figure 1, the first stage of the research envisages determination of the influence of digitalization on quality of labor in developing countries with application of regression analysis. Hypothesis $\mathrm{H}_{1}$ on contradiction of the influence is offered and verified - which envisages the presence of positive and negative coefficients of regression. For this, functions of multiple regression dependence of each $\mathrm{y}$ on $\mathrm{x}_{1}, \mathrm{x}_{2}, \mathrm{x}_{3}$ are calculated. If analysis shows that the influence is contradictory, hypothesis $\mathrm{H}_{1}$ is deemed proved; in the opposite case, it is disproved, and $\mathrm{H}_{2}$ on non-contradictory influence is accepted.

At the second stage, the prospects of harmonization of the influence of digitalization on quality of labor in developing countries are determined. For this, optimization is performed with the help of simplex method. Hypothesis $\mathrm{H}_{3}$ about the possibility of harmonization is offered. In the process of optimization, various combinations of factor variables $\left(\mathrm{x}_{1}, \mathrm{x}_{2}, \mathrm{x}_{3}\right)$ and systemic results for all $\mathrm{y}$ are considered. 
Method: regression analysis
Stage 1: Determining the influence of digitalization on labor quality in developing countries $\underline{\text { Hypothesis } \mathrm{H}_{1}}$ : influence is contradictory presence of positive and negative regression coefficients
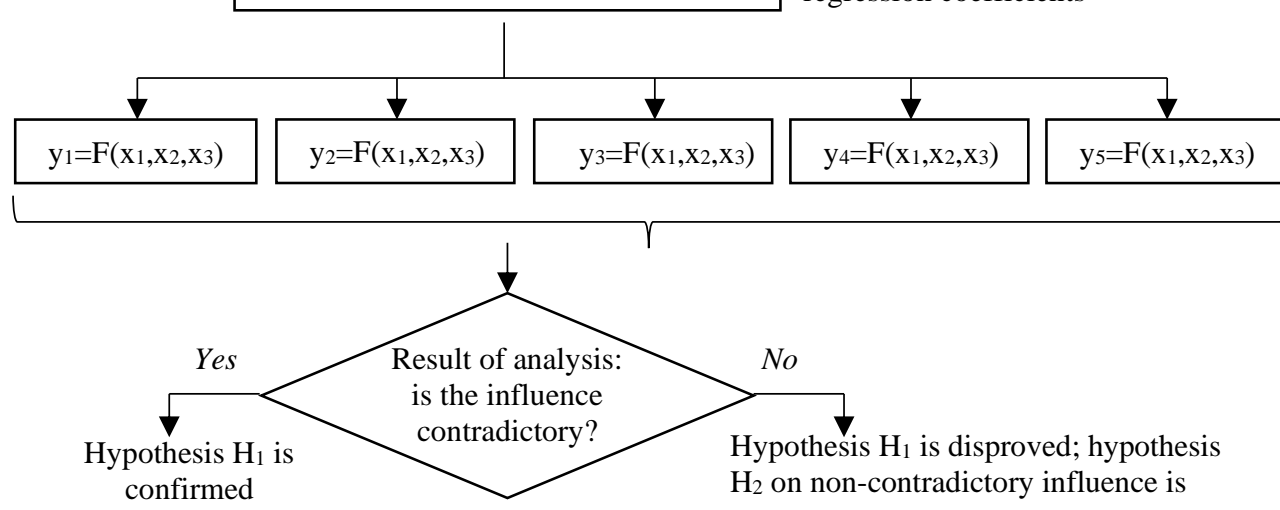

$\mathrm{H}_{2}$ on non-contradictory influence is confirmed contradictory?

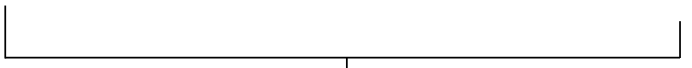

Method: optimization with simplex method
Stage 2: Determining the perspectives of harmonization of the influence of digitalization on labor quality $\underline{\text { Hypothesis } \mathrm{H}_{3}}$ : harmonization is possible

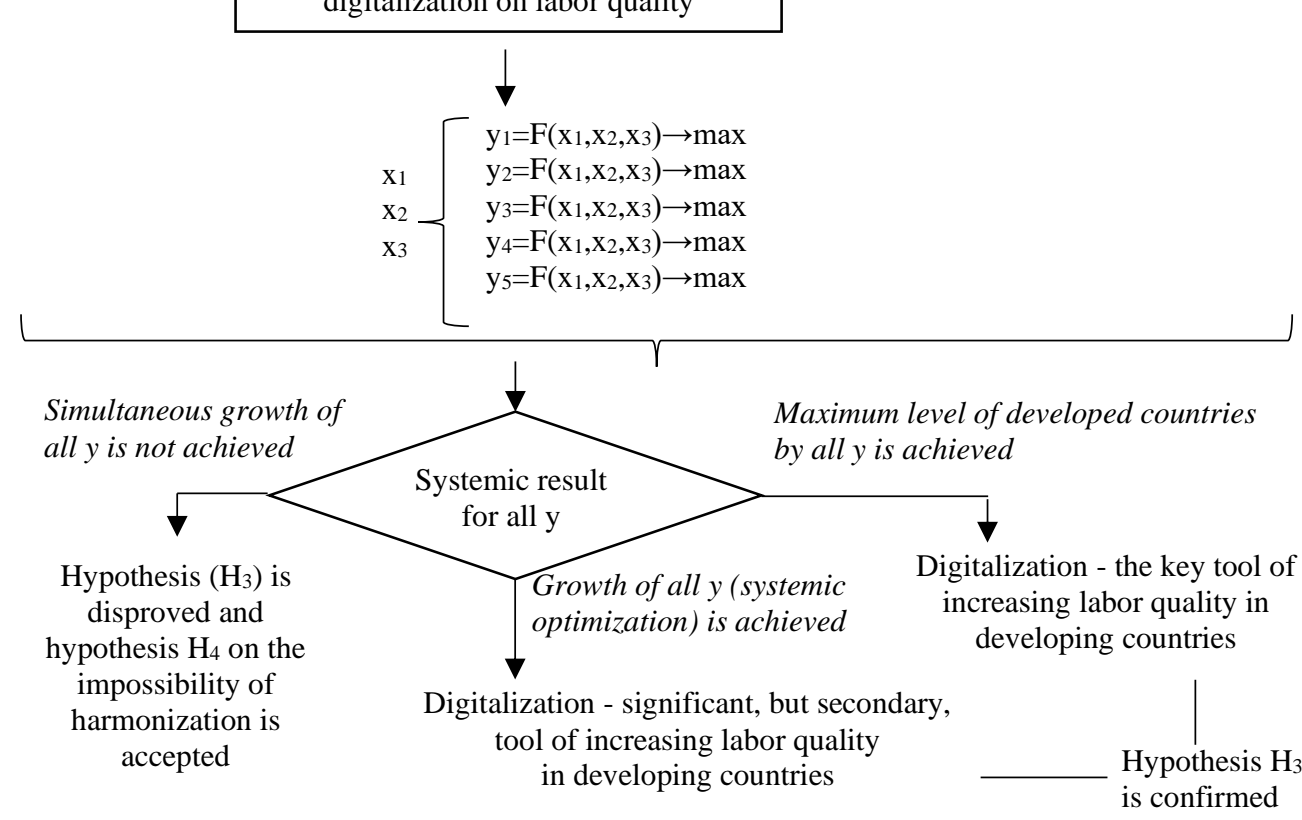

Figure 1. The research algorithm

Source: developed and compiled by the authors

If simultaneous growth of all $\mathrm{y}$ is not achieved, hypothesis $\mathrm{H}_{3}$ is deemed disproved, and hypothesis $\mathrm{H}_{4}$ on impossibility of harmonization is accepted. 
If the maximum level of developed countries for all $\mathrm{y}$ is achieved, digitalization is acknowledged as the key tool of increasing labor quality in developing countries and a mechanism of provision of the world labor market's labor. If growth of all y (systemic optimization) is achieved, but the level of developed countries is not reached, digitalization is acknowledged as a significant but secondary tool of increase of labor quality in developing countries, which cannot balance the global labor market. In both case, hypothesis $\mathrm{H}_{3}$ is considered to be proved. Depending on the obtained results, practical recommendations for improving the

\section{Labor efficiency}

$$
\text { Maximum in the.. }
$$

$$
\text { .... }
$$

Average in selected.
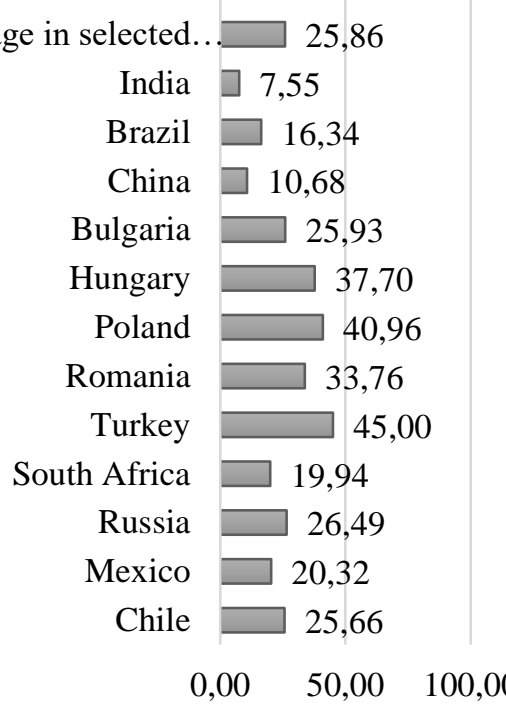

practice of management of labor quality in developing countries in the conditions of digital economy are prepared.

\section{Results}

\subsection{Contradictions of the influence of digitalization on quality of labor in developing countries}

For determining the contradictions of the influence of digitalization on quality of labor in developing countries, let us use the results of regression analysis.

$$
\begin{gathered}
\mathrm{y} 1=16.85-0.56 \times 1+1.33 \times 2- \\
0.63 \times 3, \mathrm{R} 2=0.5983
\end{gathered}
$$

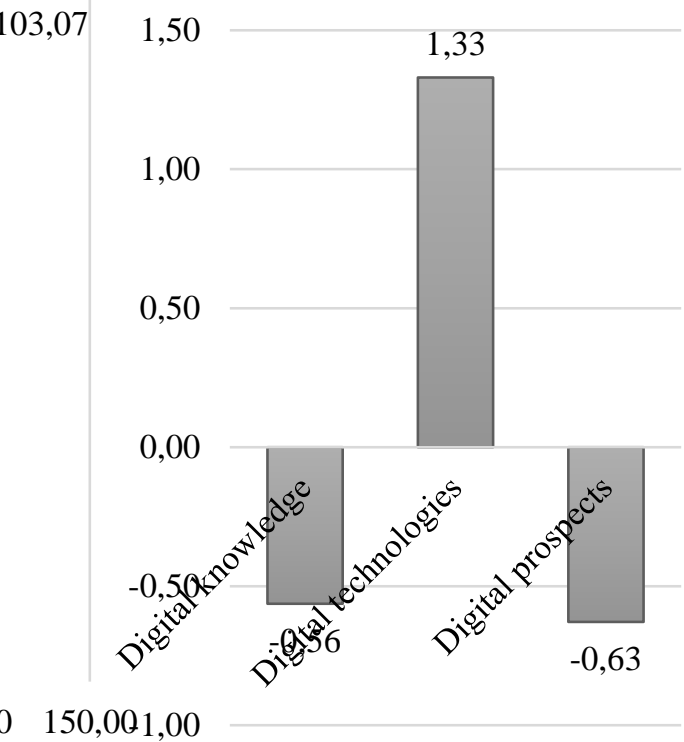

Figure 2. Labor efficiency and its dependence on digitalization in developing countries in 2020, USD

Source: calculated and compiled by the authors based on OECD (2020)

As shown in Figure 2, the highest labor efficiency among the studied developing countries in 2020 is observed in Turkey (USD 45) and Poland (USD 40.96), and the lowest in India (USD 7.55). Direct average of labor efficiency among the selection of developing countries constitutes USD 25.86. The maximum value of labor efficiency in the world in 2020 constitutes USD 103.07. Increase of digital knowledge by 1 point leads to decrease of labor efficiency in developing countries by USD 0.56 . Development of digital technologies by 1 point leads to increase of labor efficiency in developing countries by USD 1.33. Increase of digital prospects by 1 point leads to 
decrease of labor efficiency in developing countries by USD 0.63 . Multiple correlation is moderate $-59.83 \%$.

As shown in Figure 3, the highest value of human development index among the studied developing countries in 2020 is observed in Poland (0.87), Chile (0.85),

\section{Human development index}

Maximum in the.

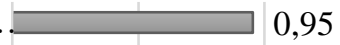

Average in selected. 0,79

India

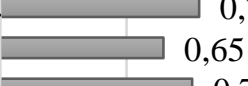

Brazil 0,76

China

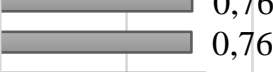

Bulgaria 0,82

Hungary $\square 0,85$

Poland 0,87

Romania 0,82

Turkey $\square 0,81$

South Africa $\longrightarrow 0,71$

Russia $\square 0,82$

Mexico 0,77

Chile

0,85

$0,00 \quad 0,50 \quad 1,00$
Hungary (0.85), Bulgaria (0.82), and Russia $(0,82)$, and the lowest in South Africa (0.71). Direct average of human development indices among the selection of developing countries constitutes 0.79 . The maximum value of human development index in the world in 2020 equals 0.95 .
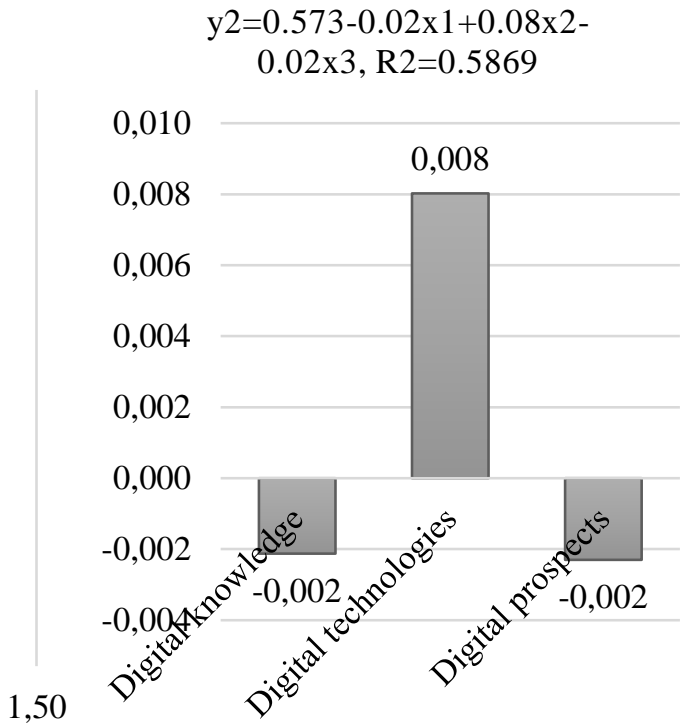

Figure 3. Human development index and its dependence on digitalization in developing countries in 2020, shares of 1

Source: calculated and compiled by the authors based on UNDP (2020)

Increase of digital knowledge by 1 point leads to decrease of human development index in developing countries by 0.002 . Development of digital technologies by 1 point leads to increase of human development index in developing countries by 0.008 . Increase of digital perspectives by 1 point leads to decrease of human development index in developing countries by 0.002 . Multiple correlation is moderate $58.69 \%$.

As shown in Figure 2, the most effective stimulation of labor among the studied developing countries in 2020 is observed in China (60.5 points), Russia (58.9 points), and Chile (56.0 points), and the least effective in Brazil (40.4 points). Direct average of effectiveness of labor stimulation in the selection of developing countries equals 49.25 points. The maximum value of effectiveness of labor stimulation in the world in 2020 constitutes 100.00 points.

Increase of digital knowledge by 1 point leads to increase of effectiveness of labor stimulation in developing countries by 0.46 points. Development of digital technologies by 1 point leads to decrease of effectiveness of labor stimulation in developing countries by 0.24 points. Increase of digital prospects by 1 point leads to increase of effectiveness of labor stimulation in developing countries by 0.36 points. Multiple correlation is high $87.77 \%$. 
Stimulation of labor

Maximum in the.

Average in. .

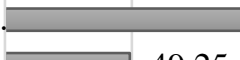

India

Brazil

China

Bulgaria

Hungary

Poland

Romania

Turkey

South Africa

Russia

Mexico

Chile

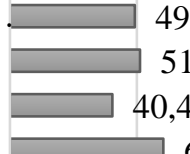

49,25

51,3

60,5
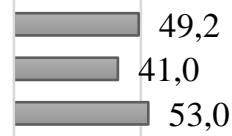

$\square 4,6$

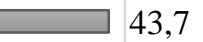

$\square 46,0$

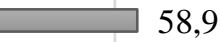

$\square 6,4$

$0,0 \quad 50,0 \quad 100,0$
100,00

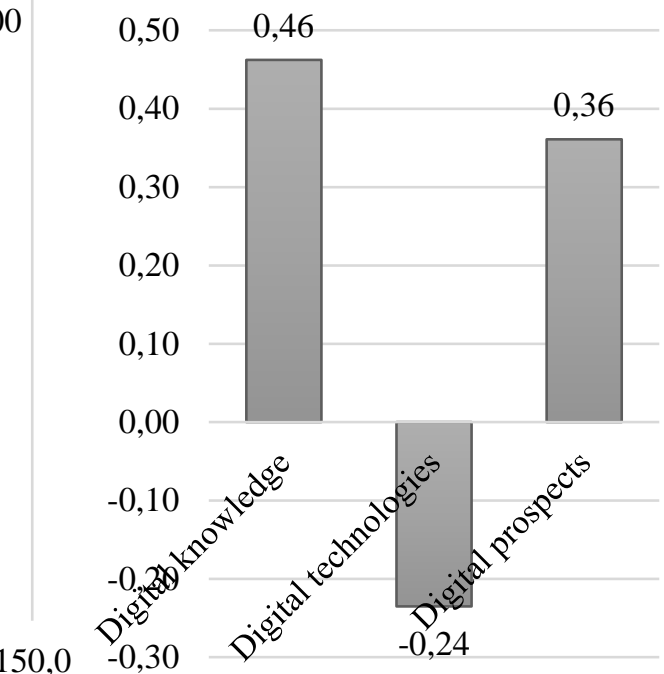

150,0

$\mathrm{y} 3=14.93+0.46 \mathrm{x} 1-$

$0.24 \times 2+0.36 \times 3, R 2=0.8777$

Figure 4. Stimulation of labor and its dependence on digitalization in developing countries in 2020 , points $1-100$

Source: calculated and compiled by the authors based on World Economic Forum (2020)

Share of hi-tech products in indusrial export

$$
\begin{gathered}
\mathrm{y} 4=- \\
25.85+0.14 \times 1+0.32 \times 2+0.16 \times 3, \\
\mathrm{R} 2=0.5891
\end{gathered}
$$

Maximum in the world

Average in selected.

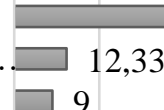

India

Brazil

China

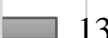

Bulgaria

Hungary

Poland

Romania

Turkey ] 2

South Africa

Russia

Mexico

Chile

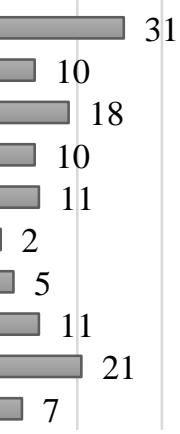

$\begin{array}{lll}0 & 20 \quad 40\end{array}$
66,00

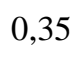

0,30

0,25

0,20

0,15

0,10

0,05

0,00

0,32

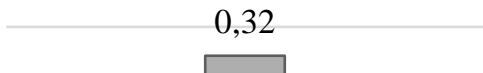

$-$

0,17
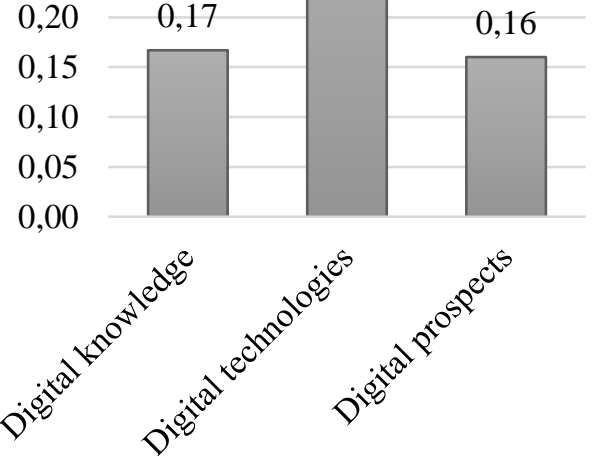

Figure 5. Share of hi-tech products in the structure of industrial export and its dependence on digitalization in developing countries in $2020, \%$.

Source: calculated and compiled by the authors based on World Bank (2020) 
As shown in Figure 2, the highest share of hi-tech products in the structure of industrial export among the studied developing countries in 2020 is observed in China $(31 \%)$, Mexico $(21 \%)$, and Hungary (18\%), and the lowest in Turkey (2\%). Direct average of the shares of hi-tech products among the selection of developing countries constitutes $12.33 \%$. The maximum value of the share of hi-tech products in the world in 2020 constitutes $66 \%$.
Increase of digital knowledge by 1 point leads to increase of share of hi-tech products in developing countries by $0.17 \%$. Development of digital technologies by 1 point leads to increase of share of hi-tech products in developing countries by $0.32 \%$. Increase of digital perspectives by 1 point leads to increase of share of hi-tech products in developing countries by $0.16 \%$. Multiple correlation is moderate $-58.91 \%$.
Innovation index

Maximum in the Average in. .

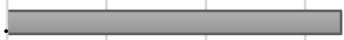

67,24

India 39,12

Brazil China 36,58 Bulgaria

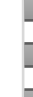
Hungary

Poland

Romania

Turkey

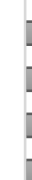

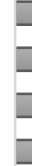

South Africa
Russia

Russia
Mexico

.

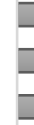

$$
0,00
$$

20,00
33,82

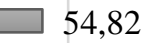

40,35

44,51

41,31

36,76

36,95

34,04

37,62

36,06

36,64

Figure 6. Innovation index and its dependence on digitalization в of developing countries в 2020 г., points $1-100$

Source: calculated and compiled by the authors based on Cornell INSEAD WIPO (2020)

As shown in Figure 2, the highest value of the innovation index among the studied developing countries in 2020 is observed in China (54.82 points), and the least value is observed in Brazil (33.82 points). Direct average of innovations indices among the selection of developing countries constitutes 39.12 points. The maximum value of innovation index in the world in 2020 constitutes 67.24 points.
Increase of digital knowledge by 1 point leads to increase of innovation index in developing countries by 0.03 points. Development of digital technologies by 1 point leads to increase of innovation index in developing countries by 0.61 points. Increase of digital perspectives by 1 point leads to increase of innovation index in developing countries by 0.15 points. Multiple correlation is high $-81.41 \%$. 
Thus, hypothesis $\mathrm{H}_{1}$ on contradiction of the influence of digitalization on quality of labor in developing countries has been proved. The influence of digitalization is different not only for its different factors but also for different characteristics of labor quality. On the whole, the influence of digital technologies, due to which quality of labor grows by most of its characteristics, is the least positive.

\subsection{Prospects of harmonization of the digitalization directions in developing countries for the purpose of increasing labor quality}

For determining the perspectives of harmonization of digitalization directions in developing countries for the purpose of increasing labor quality, let us perform optimization of this influence according to the six following goals, aimed at improvement of the characteristics of labor quality:

- Goal 1: taking average labor efficiency in developing countries up to the maximum value in the world, $\mathrm{y}_{1}=103.07$;

- Goal 2: taking the average human development index in developing countries up to the maximum value in the world, $\mathrm{y}_{2}=0.95$;

- Goal 3: taking average effectiveness of labor stimulation in developing countries up to the maximum value in the world, $\mathrm{y}_{3}=100.00$;

- Goal 4: taking average share of hitech products in the structure of industrial export in developing countries up to the maximum value in the world, $\mathrm{y}_{4}=66.00$;

- Goal 5: taking average innovation index in developing countries up to the maximum value in the world, $\mathrm{y}_{5}=67.24$;

- Goal 6: simultaneous maximization of all characteristics of labor quality, the growth of each of which should be positive, all $\mathrm{y}=\max$.
As digitalization and quality of labor could be increased only in the mid-term, optimization is planned for the period until 2024. The results of optimization with the help of simplex method based on the data from Figures 2-6 are presented in Table 2.

As shown in Table 2, taking average labor efficiency in developing countries up to the maximum value in the world (achievement of Goal 1: $\left.y_{1}=103.07\right)$ ensures the highest systemic growth of all $\mathrm{y}$ - by $114.27 \%$; however, it is accompanied by decrease of effectiveness of labor stimulation $\left(\mathrm{y}_{3}\right)$ by $27.73 \%$. Taking the average human development index in developing countries up to the maximum value in the world (achievement of Goal 3: $y_{2}=0.95$ ) ensures the systemic growth of all $y$ by $39.59 \%$; however, it is accompanied by decrease of effectiveness of labor stimulation $\left(\mathrm{y}_{3}\right)$ by $9.61 \%$.

Taking average effectiveness of labor stimulation in developing countries up to the maximum value in the world (achievement of Goal 3: $\mathrm{y}_{3}=100.00$ ) leads to the systemic decrease of all y by $4.16 \%$ due to reduction of labor efficiency $\left(\mathrm{y}_{1}\right)$ by $277.28 \%$ and human development index $\left(\mathrm{y}_{2}\right)$ by $33.83 \%$. Taking average share of hi-tech products in the structure of industrial export in developing countries to the maximum value in the world (achievement of Goal 4: $\left.\mathrm{y}_{4}=66.00\right)$ ensures systemic growth of all $\mathrm{y}$ by $57.36 \%$, but is accompanied by decrease of labor efficiency $\left(\mathrm{y}_{1}\right)$ by $423.9 \%$ and human development index $\left(\mathrm{y}_{2}\right)$ by $38.62 \%$.

Taking average innovation index in developing countries up to the maximum value in the world (achievement of Goal 5: $\left.\mathrm{y}_{5}=67.24\right)$ ensures the systemic growth of all $\mathrm{y}$ by $21.08 \%$, but is accompanied by decrease of labor efficiency ( $\left.\mathrm{y}_{1}\right)$ by $472.29 \%$ and human development index $\left(\mathrm{y}_{2}\right)$ by $51.97 \%$. Simultaneous maximization of all characteristics of labor quality, the growth of each of which should be positive (achievement of Goal 6: all $y=\max$ ) ensures the systemic growth of all $\mathrm{y}$ by $78.63 \%$; growth of all $y$ is positive. 
Table 2. Harmonization of the directions of digitalization in developing countries for the purpose of increasing labor quality in the period until 2024.

\begin{tabular}{|c|c|c|c|c|c|c|c|c|c|c|c|c|}
\hline \multirow[b]{2}{*}{ Variable } & \multicolumn{2}{|c|}{$\begin{array}{c}\text { Goal 1: } \\
\mathrm{y}_{1}=103.07\end{array}$} & \multicolumn{2}{|c|}{$\begin{array}{l}\text { Goal 2: } \\
\mathrm{y}_{2}=0.95\end{array}$} & \multicolumn{2}{|c|}{$\begin{array}{c}\text { Goal 3: } \\
\mathrm{y}_{3}=100.00\end{array}$} & \multicolumn{2}{|c|}{$\begin{array}{c}\text { Goal 4: } \\
\mathrm{y}_{4}=66.00\end{array}$} & \multicolumn{2}{|c|}{$\begin{array}{c}\text { Goal 5: } \\
\mathrm{y}_{5}=67.24\end{array}$} & \multicolumn{2}{|c|}{$\begin{array}{l}\text { Goal 6: } \\
\mathrm{y}=\max \end{array}$} \\
\hline & 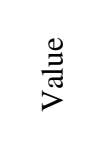 & 起 & $\frac{\mathscr{g}}{\stackrel{\pi}{~}}$ & 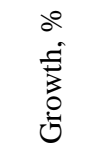 & 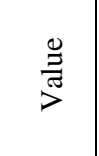 & 起 & $\stackrel{\frac{\mathscr{m}}{\pi}}{\stackrel{\pi}{>}}$ & 总 & $\stackrel{\frac{0}{\pi}}{\stackrel{\pi}{>}}$ & 起 & $\stackrel{\frac{0}{J}}{>}$ & 起 \\
\hline $\mathrm{X} 1$ & 59.02 & 0 & 59.02 & 0 & 128.03 & 116.91 & 209.76 & 255.38 & 204.49 & 246.45 & 59.02 & 0 \\
\hline $\mathrm{X}_{2}$ & 117.27 & 97.99 & 79.34 & 33.95 & 59.23 & 0 & 92.86 & 56.78 & 73.92 & 24.8 & 100 & 68.83 \\
\hline $\mathrm{X} 3$ & 58.13 & 0 & 58.13 & 0 & 110.39 & 89.9 & 168.66 & 190.13 & 153.21 & 163.56 & 85 & 46.22 \\
\hline $\mathrm{y}_{1}$ & 103.07 & 298.54 & 52.61 & 103.45 & -45.85 & -277.28 & -83.76 & -423.9 & -96.28 & -472.29 & 63.21 & 144.4 \\
\hline $\mathrm{y}_{2}$ & 1.25 & 59.04 & 0.95 & 20.46 & 0.52 & -33.83 & 0.48 & -38.62 & 0.38 & -51.97 & 1.05 & 33.64 \\
\hline $\mathrm{y}_{3}$ & 35.59 & -27.73 & 44.52 & -9.61 & 100.00 & 103.05 & 150.89 & 206.38 & 147.34 & 199.16 & 49.35 & 0.21 \\
\hline $\mathrm{y}_{4}$ & 30.97 & 151.07 & 18.79 & 52.34 & 32.23 & 161.29 & 66.00 & 435.14 & 56.57 & 358.65 & 59.72 & 141.01 \\
\hline y5 & 74.5 & 90.41 & 51.38 & 31.33 & 49.29 & 26 & 81.29 & 107.79 & 67.24 & 71.88 & 68.02 & 73.87 \\
\hline 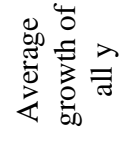 & - & 114.27 & - & 39.59 & - & -4.16 & - & 57.36 & - & 21.08 & - & 78.63 \\
\hline
\end{tabular}

Source: calculated and compiled by the authors.

For better representation and more precise comparison, growth of variables during harmonization of the digitalization directions in developing countries for the purpose of

Growth of variables, \%

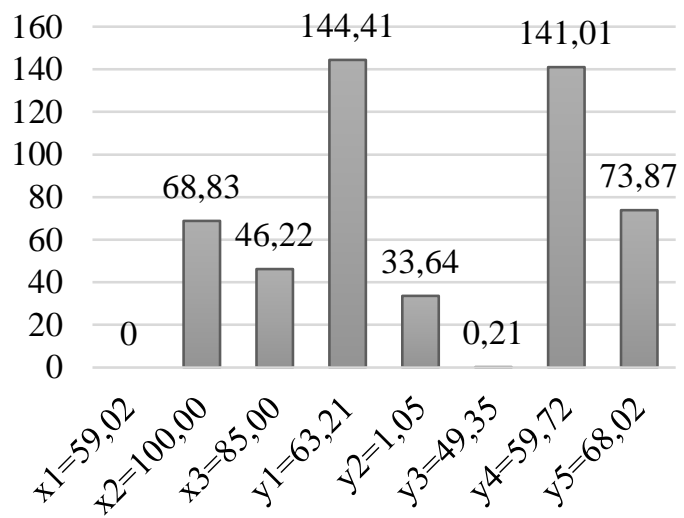

increasing labor quality in the period until 2024, depending on the goals of optimization, is shown in Figure 7.

Systemic growth of all y

Goal 1:

y $1=103.07$

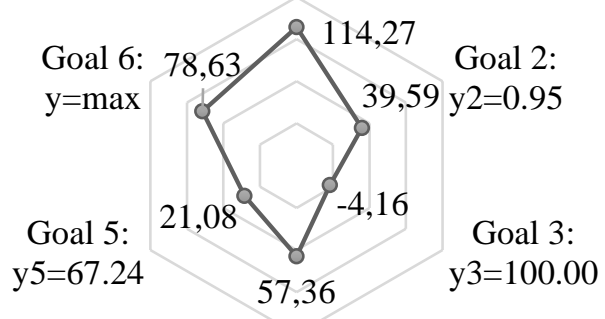

Goal 4:

$\mathrm{y} 4=66.00$

Figure 7. Growth of variables during harmonization of the digitalization directions in developing countries for the purpose of increasing labor quality in the period until 2024,

depending on the optimization goals

Source: calculated and compiled by the authors 
As shown in Figure 7, all goals of optimization cannot be achieved simultaneously. That's why digitalization could be only a secondary tool of increasing labor quality in developing countries. Harmonization of influence of digitalization on quality of labor could be achieved, which proves hypothesis $\mathrm{H}_{3}$, for according to Goal 6 growth of all $\mathrm{y}$ is positive. Thus, digital knowledge remains unchanged, digital technologies grow by $68.83 \%$, and digital perspectives grow by $46.22 \%$. This ensures the increase of labor efficiency by $144.41 \%$, human development index by $33.64 \%$, effectiveness of labor stimulation by $0.21 \%$, share of hi-tech products by $141.01 \%$, and innovation index by $73.87 \%$.

\subsection{Management implications for managing digitalization in developing countries for the purpose of increasing labor quality}

For managing digitalization in developing countries for the purpose of increasing labor quality, and for the practical implementation of Goal 6, the following management implications are offered. Firstly, for managing the development of digital technologies:

- Provision of company's access to the modern and leading telecommunication infrastructure for the maximum automatization of labor based on digital technologies. In particular, participation in clusters, technological parks, innovative networks, and special economic zones, where the infrastructure is well developed;

- Registration of ownership rights for the objects of intellectual property, obtained in the course of corporate $\mathrm{R} \& \mathrm{D}$ for achieving and supporting unique labor quality, unattainable for rivals;

- Attraction of investments in corporate digital modernization for quick implementation of the leading digital technologies in the labor practices at a company for the purpose of increasing their quality.

Secondly, for managing the increase of digital perspectives:

- Supporting adaptation and mastering of digital technologies by consumers, for automatization, based on digital technologies, of not only production but also distributive business processes and for achievement of systemic growth of labor quality at a company;

- Implementation of the leading digital technologies (robots, big data, and AI) not only in company's interests but also in the interests of employees, for creating highlyefficient and highly-paid jobs, which ensure the full implementation of qualification and creative potential of employees;

- Implementation of the leading means of data protection for supporting continuous work of digital technologies (reduction of cyber risks) and achievement of stable and high labor quality.

\section{Conclusion}

The following conclusions could be made:

1. Contradictions of the influence of digitalization on quality of labor in developing countries have been determined. Digital technologies stimulate the improvement of all characteristics of labor, apart from labor stimulation, and the simultaneous positive influence of the digitalization factors on quality of labor is achieved only for such characteristics as share of hi-tech products and innovation index;

2. Prospects of harmonization of the digitalization directions in developing countries for the purpose of increasing labor 
quality are rather wide. It is possible to achieve isolated optimization, at which quality of labor reaches the maximum level in the world, but only according to one characteristic (separately). Simultaneous achievement of the maximum world values for all characteristics of labor quality by means of digitalization is impossible. However, systemic optimization, at which simultaneous growth of all characteristics of labor quality is achieved, is possible. Maximum systemic (simultaneous) growth of these characteristics in developing countries in the period until 2024 constitutes $78.63 \%$;

3. Harmonization of the digitalization directions in developing countries for the purpose of increasing labor quality in the period until 2024 envisages increase of the level of development of digital technologies by $68.83 \%$ and digital perspectives by $46.22 \%$. Management implications, which allow managing the digitalization in developing countries for the purpose of increasing labor quality, are offered.

The contribution of this research to development of the scientific and economic theory consists in specifying the characteristics and developing the systemic treatment of quality, which includes labor efficiency, human development, stimulation of labor, increase of share of production and export of hi-tech products, and increase of innovative activity. Theoretical significance of the research consists also in substantiating the contradiction of the influence of digitalization on quality of labor and determining the perspectives of harmonization of this influence in developing countries.
Contribution of the obtained results to development of the practice of labor quality management is ensures by development of the management implications for labor quality management based on digitalization in companies' activities in developing countries. Practical significance of the research is also connected to maximum detalization of conclusions and recommendations, which simplifies their practical application.

It should be noted that the performed research allows for an unexpected conclusion: development of digital knowledge has moderate positive influence on increase of labor quality in developing countries, and increase of digital knowledge is not required for harmonization of the influence of digitalization on quality of labor in countries of this category. This sets a new question: how quality of labor could be increased based on digitalization in case of insufficient digital technologies with employees (low digital competence). This issue should be studied in further works.

Acknowledgements: This article was prepared as part of the government contract as requested by the Ministry of Science and Higher Education of the Russian Federation on the subject formulated as «Structural changes in economy and society as a result of achieving the target indicators of National projects, which provide opportunities to organize new areas of social and economic activity, including commercial, both in Russia and abroad» (project No. FSSW2020-0010).

\section{References:}

Aboobaker, N., \& K. A., Z. (2019). Influence of digital learning orientation and readiness for change on innovative work behaviour: reflections from the higher education sector. Development and Learning in Organizations, 34(2), 25-28. https://doi.org/10.1108/DLO-082019-0191 
Alpidovskaya, M. L., \& Popkova, E. G. (2019). Marx \& Modernity: A Political and Economic Analysis of Social Systems Management. A volume in the series Popkova, E.G. (Ed.) Advances in Research on Russian Business and Management, Charlotte, NC, USA, Information Age Publishing.

Amladi, P. (2017). HR's guide to the digital transformation: ten digital economy use cases for transforming human resources in manufacturing. Strategic HR Review, 16(2), 6670. https://doi.org/10.1108/SHR-12-2016-0110

Bachmann, J. (2019). Household consumption change in the context of labour market changes in Japan during 1984-2014. Review of Behavioral Finance, 12(3), 223241. https://doi.org/10.1108/RBF-12-2018-0134

Baro, E. E., Obaro, O. G., \& Aduba, E. D. (2019). An assessment of digital literacy skills and knowledge-based competencies among librarians working in university libraries in Africa. Digital Library Perspectives, 35(3/4), 172-192. https://doi.org/10.1108/DLP-04-2019-0013

Bejaković, P., \& Mrnjavac, Ž. (2020). The importance of digital literacy on the labour market. Employee Relations, 42(4), 921-932. https://doi.org/10.1108/ER-07-2019-0274

Bogoviz A. V., Lobova S. V., \& Alekseev A. N. (2020a). Current state and future prospects of hydro energy in Russia. International Journal of Energy Economics and Policy, 10(3), 482488.

Bogoviz A. V., Lobova S. V., \& Alekseev A.N. (2020b). Social development versus economic growth: current contradictions and perspectives of convergence. International Journal of Sociology and Social Policy. https://doi.org/10.1108/IJSSP-03-2020-0061

Bogoviz A. V., Lobova S. V., Karp M. V., Vologdin E.V., \& Alekseev A. N. (2019a). Diversification of educational services in the conditions of industry 4.0 on the basis of ai training. On the Horizon. 27(3-4), 206-212.

Bogoviz A. V., Prokofiev V. N., Lobova S. V., Alekseev A. N., \& Gimelshtein I. V. (2019b). Managing the modernization of regional markets of educational services in the conditions of formation of industry 4.0. On the Horizon, 27(3-4), 187-192.

Bucher, E., Fieseler, C., \& Lutz, C. (2019). Mattering in digital labor. Journal of Managerial Psychology, 34(4), 307-324. https://doi.org/10.1108/JMP-06-2018-0265

Calavrezo, O. (2007). The Effects of Fixed-term Employment Spells on the Integration of School-leavers on the Labour Market: Evidence from France. International Journal for Quality research, 1(4), 267-279.

Cornell INSEAD WIPO (2020). Global innovation index 2019. Retrieved from: https://www.globalinnovationindex.org/gii-2019-report (data accessed: 15.08.2020).

Das, R. (2019). Diversity management as a strategic human resource agenda: critique and roadmap. Strategic HR Review, 18(1),26-29. https://doi.org/10.1108/SHR-10-2018-0084

DiClaudio, M. (2019). People analytics and the rise of HR: how data, analytics and emerging technology can transform human resources (HR) into a profit center. Strategic HR Review, 18(2), 42-46. https://doi.org/10.1108/SHR-11-2018-0096

Fan, H., Dong, Y., Hu, D., \& Luo, L. (2018). Do labour unions mitigate labour conflicts in China's manufacturing firms? Evidence from the China employer-employee survey. International Journal of Conflict Management, 29(4), 470486. https://doi.org/10.1108/IJCMA-09-2017-0116 
Garcia-Carbonell, N., Martin-Alcazar, F., \& Sanchez-Gardey, G. (2018). Human capital in top management teams seen through the lens of senior human resources managers: An exploratory analysis. European Business Review, 30(5), 571590. https://doi.org/10.1108/EBR-03-2017-0064

IMD (2020). World Digital Competitiveness Ranking 2019. Retrieved from: https://www.imd.org/wcc/world-competitiveness-center-rankings/world-digitalcompetitiveness-rankings-2019/ (data accessed: 15.08.2020).

Inshakova, A. O., \& Bogoviz, A. V. (Ed.) (2020). Alternative Methods of Judging Economic Conflicts in the National Positive and Soft Law. A volume in the series Popkova, E.G. (Ed.) Advances in Research on Russian Business and Management, Charlotte, NC, USA, Information Age Publishing.

International Monetary Fund (2020). World Economic Outlook Database. Retrieved from: https://www.imf.org/external/pubs/ft/weo/2017/01/weodata/weoselgr.aspx (data accessed: 15.08.2020).

Irum, A., \& Yadav, R. S. (2019). Human resource information systems: a strategic contribution to HRM. Strategic Direction, 35(10), 4-6. https://doi.org/10.1108/SD-02-2019-0043

Ishmael-Robertson, C. A. (2018). What are the key advances in human resource development that tourism in Guyana needs by 2025? Worldwide Hospitality and Tourism Themes, 10(5),605-610. https://doi.org/10.1108/WHATT-05-2018-0034

Jha, S., \& Bhattacharyya, S. S. (2017). Shifting contours of strategic human resource management in India. Strategic HR Review, 16(5),241-243. https://doi.org/10.1108/SHR-052017-0028

Lekchiri, S. (2017). Global human resource development: regional and country perspectives - a book review. European Journal of Training and Development, 41(5), 485488. https://doi.org/10.1108/EJTD-04-2017-0036

Maurer, R. (2017). The challenge of building support for human resource programs. Strategic HR Review, 16(3), 131-135. https://doi.org/10.1108/SHR-02-2017-0012

OECD (2020). GDP per hour worked, Total, US dollars. Retrieved from: https://data.oecd.org/lprdty/gdp-per-hour-worked.htm (data accessed: 15.08.2020).

Oguzertem, I. (2019). What are the barriers to integrating displaced populations into labor markets and what are possible steps to overcome them?. Career Development International, 25(1), 19-23. https://doi.org/10.1108/CDI-12-2018-0309

Okeji, C. C., Tralagba, E. C., \& Obi, I. C. (2019). An investigation of the digital literacy skills and knowledge-based competencies among librarians working in university libraries in Nigeria. Global Knowledge, Memory and Communication, 69(4/5), 311330. https://doi.org/10.1108/GKMC-05-2019-0054

Our World in Data (2020). GDP per hour worked, Total, US dollars. Retrieved from: https://ourworldindata.org/grapher/labor-productivity-per-hourpennworldtable?tab=table\&time=1970..latest (data accessed: 15.08.2020).

Pandey, J. (2018). Managing emotional labor for service employees: an HRM-based approach. Human Resource Management International Digest, 26(4), 14. https://doi.org/10.1108/HRMID-04-2017-0072

Plaskoff, J. (2017). Employee experience: the new human resource management approach. Strategic HR Review, 16(3), 136-141. https://doi.org/10.1108/SHR-12-2016-0108 
Pope, C., \& Turnbull, J. (2017). Using the concept of hubots to understand the work entailed in using digital technologies in healthcare. Journal of Health Organization and Management, 31(5), 556-566. https://doi.org/10.1108/JHOM-12-2016-0231

Popkova, E. G., \& Sergi, B. S. (2020). Human Capital and AI in Industry 4.0. Convergence and Divergence in Social Entrepreneurship in Russia. Journal of Intellectual Capital, https://doi.org/10.1108/JIC-09-2019-0224.

Popkova, E. G. (2017). Economic and Legal Foundations of Modern Russian Society. A volume in the series Popkova, E.G. (Ed.) Advances in Research on Russian Business and Management, Charlotte, NC, USA, Information Age Publishing.

Popkova, E. G. (2019). Preconditions of formation and development of industry 4.0 in the conditions of knowledge economy. Studies in Systems, Decision and Control, 169(1), 65-72.

Popkova, E. G. (2020). A new treatment of quality of goods and services in the conditions of the knowledge economy: opposition of traditions and innovations. International Journal for Quality Research, 14(2), 329-346. https://doi.org/10.24874/IJQR14.02-01.

Popkova, E. G., Przhedetsky, Yu V., Przhedetskaya, N. V., \& Borzenko, K.V. (Ed.) (2020). Marketing of Healthcare Organizations: Technologies of Public-Private Partnership. A volume in the series Popkova, E.G. (Ed.) Advances in Research on Russian Business and Management, Charlotte, NC, USA, Information Age Publishing.

Popkova, E. G., Poluyufta, L., Beshanova, Y., Popova, L. V., \& Kolesnikova, E. (2017). Innovations as a basis for marketing strategies of Russian oil companies in the conditions of oil prices reduction. Contributions to Economics, (9783319606958), 449-455. https://doi.org/10.1007/978-3-319-60696-5_57

Popkova, E. G., \& Sergi, B. S. (2018). Will Industry 4.0 and Other Innovations Impact Russia's Development? In Bruno S. Sergi (Ed.) Exploring the Future of Russia's Economy and Markets: Towards Sustainable Economic Development (pp. 51-68). Bingley, UK: Emerald Publishing Limited.

Popkova, E. G., \& Sergi, B. S. (Eds.) (2019). Digital Economy: Complexity and Variety vs. Rationality. Berlin, Springer International Publishing.

Ragulina, Y. V. (2019). Priorities of development of industry 4.0 in modern economic systems with different progress in formation of knowledge economy. Studies in Systems, Decision \& Control, 169, 167-174.

Rana, G., \& Sharma, R. (2019). Emerging human resource management practices in Industry 4.0. Strategic HR Review, 18(4), 176-181. https://doi.org/10.1108/SHR-01-2019-0003

Sarkar, S. \& Liu, M. (2019). How the changing relationship between labour and political party influenced growth of autonomous labour unions in Taiwan. Employee Relations, 41(4), 758772. https://doi.org/10.1108/ER-06-2018-0160

Savoia, M., Stefanovic, M., \& o Fragassa, C. (2016). Merging technical competences and human resources with the aim at contributing to transform the Adriatic area in a stable hub for a sustainable technological development. International Journal for Quality Research, 10(1) 1-16. https://doi.org/10.18421/IJQR10.01-00

Sergi, B.S., Popkova, E.G., Bogoviz, A.V. \& Litvinova, T.N. (2019a). Understanding Industry 4.0: AI, the Internet of Things, and the Future of Work. Bingley, UK: Emerald Publishing Limited.

Sergi, B.S., Popkova, E.G., Bogoviz, A.V. \& Ragulina, J.V. (2019b). Costs and Profits of Technological Growth in Russia. In Bruno S. Sergi (Ed.) Tech, Smart Cities, and Regional Development in Contemporary Russia (pp. 41-54). Bingley, UK: Emerald Publishing. 
Sergi, B. S., Popkova, E. G., Bogoviz, A. V., \& Ragulina, J. V. (2019c). Entrepreneurship and Economic Growth: The Experience of Developed and Developing Countries. In Bruno S. Sergi and Cole C. Scanlon (Eds.) Entrepreneurship and Development in the 21st Century (pp. 3-32). Bingley, UK: Emerald Publishing Limited.

Shulus, A. A., Akopova, E. S., Przhedetskaya, N. V., \& Borzenko, K. V. (2020). Intellectual Production and Consumption: A New Reality of the 21st Century. Lecture Notes in Networks and Systems, 92, 353-359.

Stanovcic, T., Bacovic, M., Pekovic, S., Jovanovic, J., \& Savovic, I. (2016). The role of human resource practices on profits generated by the innovations: the role of top management support and regularity of employees meetings. International Journal for Quality Research, 10(4), 839-846. https://doi.org/ 10.18421/IJQR10.04-13

Susilowati, L., Ananda, C. F., Khusnul, A., \& Susilo, S. (2019). Labour productivity in micro and small industries (research on leather craftsmen in magetan regency). International journal for quality research, 14(1), 111-128. https://doi.org/10.24874/IJQR14.01-08

UNDP (2020). Human Development Report 2019. Retrieved from: http://www.hdr.undp.org/en/2019-report/download (data accessed: 15.08.2020).

Wang, L., Chai, Y., \& Liu, Y. (2017). Analysis of e-commerce transaction system's division of labor based on essential services quantity. International Journal of Crowd Science, 1(3), 197-209. https://doi.org/10.1108/IJCS-08-2017-0015

World Bank (2020). Indicators: High-technology exports (\% of manufactured exports). Retrieved from: https://data.worldbank.org/indicator/TX.VAL.TECH.MF.ZS?view=chart (data accessed: 15.08.2020).

World Economic Forum (2020). The Global Competitiveness Report 2019: Pay and productivity. Retrieved from: http://reports.weforum.org/global-competitiveness-report2019/competitiveness-rankings/\#series=EOSQ137 (data accessed: 15.08.2020).

Yadav, C. L. (2020). An introduction of cultural rights of labour in Maritime employment in India. International Journal of Law and Management, 62(2), 139145. https://doi.org/10.1108/IJLMA-03-2019-0064

$\begin{array}{lll}\text { Alexander N. Alekseev } & \text { Svetlana V. Lobova } & \text { Aleksei V. Bogoviz } \\ \text { Plekhanov Russian } & \text { Altai State University, } & \text { Independent Researcher, } \\ \text { University of Economics, } & \text { Barnaul, Russia } & \text { Moscow, Russia } \\ \text { Moscow, Russia } & \text { barnaulhome@mail.ru } & \text { aleksei.bogoviz@gmail.com } \\ \text { Alexeev alexan@mail.ru } & & \end{array}$


QUALITY International Journal for Quality Research 